\title{
Improvement in the Quality of Students' Writings: Six Case Studies
}

\section{Kazue Komiyama \\ Kyoto University of Foreign Studies}

\section{Reference Data:}

Komiyama, K. (2019). Improvement in the quality of students' writings: Six case studies. In P. Clements, A. Krause, \& P. Bennett (Eds.), Diversity and inclusion. Tokyo: JALT.

The purpose of this study was to examine whether writing practice without grammatical feedback improved the quality of high school students' essays. Japanese 12th grade students wrote a series of essays on assigned topics as homework. Two cases were given explicit grammatical correction as feedback and the other cases were given only communicative feedback related to the content. Even though students were not instructed to write as much as possible, over the course of the study their essays grew longer overall and had more words per sentence as well as a greater variety of words used. One factor in this growth, noted in an impressionistic rating of the quality of the essays, was the increase in the number of postnominal modifiers. The results suggested that freewriting exercises improve the overall quality of students' writing and their ability to use the grammar and vocabulary they know to communicate in English without grammar correction feedback.

この研究の目的は、文法訂正のフィードバックを受けること無しに、自由作文の上達が期待できるかどうか調べることであ つた。日本人高校3年生が、授業外の活動として、タイトルの与えられた自由作文を練習した。そのうち、明示的な文法訂正のフ イードバックを受けた2例と、内容に対するコメントをフィードバックされた4例について、時間の経過によるテキストの变化を 調査したどの学習者も、多くの量を書くように指示されなくても、練習回数が堌えるにつれ、全体での使用語数が増える傾向 にあることが分かつたこの伸びの一つの要因として、また、作品への質の評価が高まつたという印象の要因として、後置修飾 の使用が增えたことがあった。上の実験とケーススタディでは 文法訂正のフィードバックがなくても書くことによつて全体 的に生徒のライティングの質は向上し、英語でコミュニケーションをとるための文法や語彙使用に伸びが見られた。

urveys by the Ministry of Education, Culture, Sports, Science and Technology (MEXT) show a lack of attention to writing activities in Japanese public high schools (MEXT, 2012, 2018). Fewer than 50\% of the teachers reported using any writing-oriented activities. A survey of English teachers teaching in public high schools in Shiga Prefecture (Komiyama, 2018) showed much the same lack of attention to writing. Another indication of the lack of interest in writing instruction was seen in Ehara, Murakoshi, and Parise (2018), where it was reported that when 15 teachers in a teacher training program were asked to choose one skill to focus on in their action research program following their training, two chose listening, six chose reading, and seven chose speaking. None chose writing.

Reasons given for this lack of attention to writing varied, but the most common reasons are (a) the amount of time needed to read and provide explicit corrective feedback, especially grammatical correction, for a typical high school class of 40 or more students; (b) a lack of confidence on the part of many English teachers in their own ability to make such corrections; (c) a lack of experience on the part of many teachers in writing in English themselves; and (d) a lack of class time for in-class writing activities (Komiyama, 2018).

Even when writing activities do occur, according to the surveys previously mentioned, they are all too often Japanese-English translation practices or retranslation of Japanese translations of sentences from the textbook used to illustrate particular grammatical patterns (復文練習 fukubun renshuu, below “retranslation”). Free essay writing or semifreewriting exercises like describing one's favorite food are generally avoided.

The current stated goal of MEXT is for at least $50 \%$ of students graduating from public high schools to be able to read, write, comprehend through listening, and speak at the A2 level of the CEFR-J standard rubric (MEXT, 2018). In fact, however, fewer than $20 \%$ of Japanese high school graduates reach this level in writing (MEXT, 2018). Likely, a lack of attention to writing as a productive, communicative skill is a major reason for this lack of achievement. Similarly, the goal for speaking is met by only $12.9 \%$. In comparison, the goal for reading is met by $33.5 \%$, and that for listening is met by $33.6 \%$. Clearly the achievement is much higher for receptive skills than for productive skills. 
Although in its current form, the Center Test does not require any essay writing for students who are planning to go to universities, the second round of entrance exams at each university often require the applicants to write a short essay in English. That is, universities expect students to be trained to write English essays at the high school level It is a crucial issue to fill the gap between the expectations from universities and the reality of high school education. The purpose of this study is to examine whether essay writing practice can lead to improvements in writing ability without being prohibitive for high school teachers in terms of marking time.

\section{Previous Studies}

Truscott (1996) questioned the effectiveness of corrective feedback in helping students to improve accuracy in their writing. Ferris (1999) insisted that correction helps students' accuracy and the controversy over the effectiveness of feedback still continues. Fazio (2001) found corrective feedback in writing was not always helpful, especially when students have other chances to receive grammatical feedback. According to her findings, Japanese high school students should not gain much benefit from corrective feedback when they practice writing because most of the instruction in English classes is heavily grammar focused. Kepner (1991) examined students' journals and analyzed the data dividing students into high and low proficiency groups. Her research suggests message-related comments help students improve the content of their writing, but the sole contribution of grammatical feedback is to raise the accuracy of lower proficiency students to the same level as higher proficiency students; no increase in the accuracy of higher proficiency students was observed and the ideational content of the grammar feedback group was inferior to that of the content-oriented feedback group. Semke (1984) concluded that "student progress is enhanced by writing practice alone" (p. 195) after comparing four different types of feedback. The preponderance of these studies, then, suggests that when students receive grammatical instruction in their language program, grammatical correction in writing activities is not necessary and may even have a negative effect.

Komiyama (2016) described an experiment designed to measure differences, both positive and negative, in the grammatical performance of students in a 10-minute writing exercise program in which teachers provided communicative feedback with little grammatical correction compared to students not in the program. Group A $(n=$ 80) practiced 10-minute writing. Group B $(n=80)$ practiced retranslating into English the Japanese translations of English sentences. Group C $(n=40)$ practiced 10-minute writing and retranslating English sentences. Group D $(n=80)$ practiced neither of these activities, but did English to Japanese translation activities. A statistical analysis (Wilcoxon $\mathrm{W}$ ) of the changes in the average grammar scores for each group showed that although all four groups improved, the gains of both Group A (10-minute writing) and Group C (mixed) were significantly larger than those of Groups B (retranslation) and D (no focused activity). That is, simply the addition of written communicative activities with no corrective feedback led to improved grammatical performance.

Another study by Komiyama (2017) showed holistic judgments and factors related to fluency also increased when students were given an opportunity to use English as a medium for written communication. In one class $(n=19)$, the teacher gave a 10-minute grammar quiz once a week. In the other class $(n=18)$, the teacher used this time for a 10-minute writing exercise. At the end of the semester during which the experiment was conducted, both classes took the same final exam that included an essay question asking the students to argue for or against Saturday classes. The essays from both classes were typed up and put in random order, then rated holistically on a 1 to 10 scale by four native English speakers for whom inter-rater reliability was very high (Cronbach $\alpha=.874$ ).

The Mann-Whitney $\mathrm{U}$ test showed the average ratings assigned to the essays from the 10 -minute writing group by the native speaker raters to be significantly higher than those of the other group $(p=.017, r=.39)$. The 10-minute writing group was also significantly higher on each of the fluency measures, except in the variety of grammar patterns used, on which it was higher but not at a $p<.05$ level.

These results are especially interesting in light of the findings of Herder and King (2012). They found that a 10-minute writing program implemented at an academically highly ranked private girls' high school increased the fluency of students at all levels and, additionally, led to greater complexity in the writing of higher level students and increased accuracy by lower level students.

The results of the studies suggest that it is possible to increase students' writing fluency in an efficient and effective way taking into account (a) the amount of time for correction, (b) a lack of confidence by teachers, (c) a lack of experience on the part of teachers, and (d) a lack of class time. In short, even without corrective feedback, students can improve their writing skills, including their grammatical performance.

\section{Purpose of Study}

The purpose of this study was to examine whether writing practice without grammatical feedback improves the quality of Japanese high school students' essays. The studies previously described were cross-sectional studies that compared students participating in the 10-minute writing program with those not participating. Two 
characteristics of the programs were the lack of grammar feedback and the in-class, time-bound nature of the activity. The previous studies have shown that the writing of students in the programs improved in fluency, both in quantitative measures like total number of words used, words per sentence, and number of different words used (word types) and in holistic evaluations of overall fluency as judged by native English speakers. The present study looked at the progress of six 3rd-year students preparing for college entrance exams by writing short, 10 - to 20 -minute self-timed essays.

\section{Procedure and Methodology}

In 2016, two students each wrote a series of essays in preparation for college entrance examinations that would include an essay portion. Student A wrote 23 essays over a period of 4 weeks on topics from an exam preparation book (Gallagher, 2001). Student B wrote 11 essays on topics previously appearing on entrance exams for his target university. Both wrote their essays at home, spending 20 minutes (self-timed) on each and received general comments on paragraph structure and overall organization as well as unfocused, explicit grammatical correction and suggestions on vocabulary choice.

The other four students were members of English Expression classes with a total enrollment of 62 in 2017. They all wrote 11 or more essays as required homework that was graded simply as handed in or not. They were selected as being similar to the two students in 2016 in terms of their English ability as reflected in their class rankings and performance on mock entrance exams. The feedback conditions for these four students, however, were different from the first two: They received little or no grammar or vocabulary correction but did receive feedback on essay content.

Their essays were typed and input to the Word Level Checker (Someya, 2009) to count the number of words, the number of different words (word types), and the average sentence length in words. The data was analyzed using Spearman rank correlation in order to examine the relationship between the number of essays written and student performance.

Their essays were also analyzed for use of postnominal modification constructions. Both English and Japanese have prenominal modification - a red book-but only English has postnominal structures like the following:

1. Noun + preposition phrase (the book on the table)

2. Noun + adjective (a book full of illustrations, nature red in tooth and claw)
3. Noun + participle (present, past) (the book missing from the shelf/written by him)

4. Noun + infinitive (a book to read)

5. Noun + relative clause (the man who bought the book)

6. Noun + appositive clause (the news that the book had appeared)

7. Noun + example (a book such as that one, a book like this one)

As a measure of students' use of new constructions in the target language, the uses of postnominal modifiers were counted.

Results

Although the period over which Student A wrote his series of essays was only a month examination of his first and last essays showed a clear improvement (see Appendix A). Some of the improvement was due to a better overall essay structure and other improvements were due to fluency measures such as total number of words, number of word types, and number of words per sentence. Although the results fluctuated with the topic of each essay, linear least squares regression showed a clear increase in each of these fluency measures (see Figures 1-3).

Spearman rank correlation analysis shows $r=.32$ for the total number of words in each essay compared with the essay number $(p=.29)$. The result does not show a significant correlation and the effect size is medium. The number of different words in each essay and times Student A practiced did not show a significant correlation either $(p=.07)$. However, $r=.38$, which shows the effect size to be medium. The average sentence length shows a small effect size $(r=.13)$ and it is not statistically meaningful $(p=.52)$.

As did Student A, Student B spent 20 minutes on each essay and received both general comments on organization and specific, explicit grammatical and vocabulary correction. Student B showed an improvement in vocabulary usage, which did not appear in Student A's essays. According to Spearman rank correlation, none of the three measures (total number of words [ $p=.62, r=.15]$, total number of different word types [ $p=.78, r=.09]$, or average sentence length and number of essays $[p=.14, r=.46]$ ) showed a significant correlation.

Both of these students received extensive feedback, and both showed similar results. Even though the number of essays written by Student B was about half that of Student A, Student B's overall essay structure and fluency both improved, although the improvement was not statistically significant. 


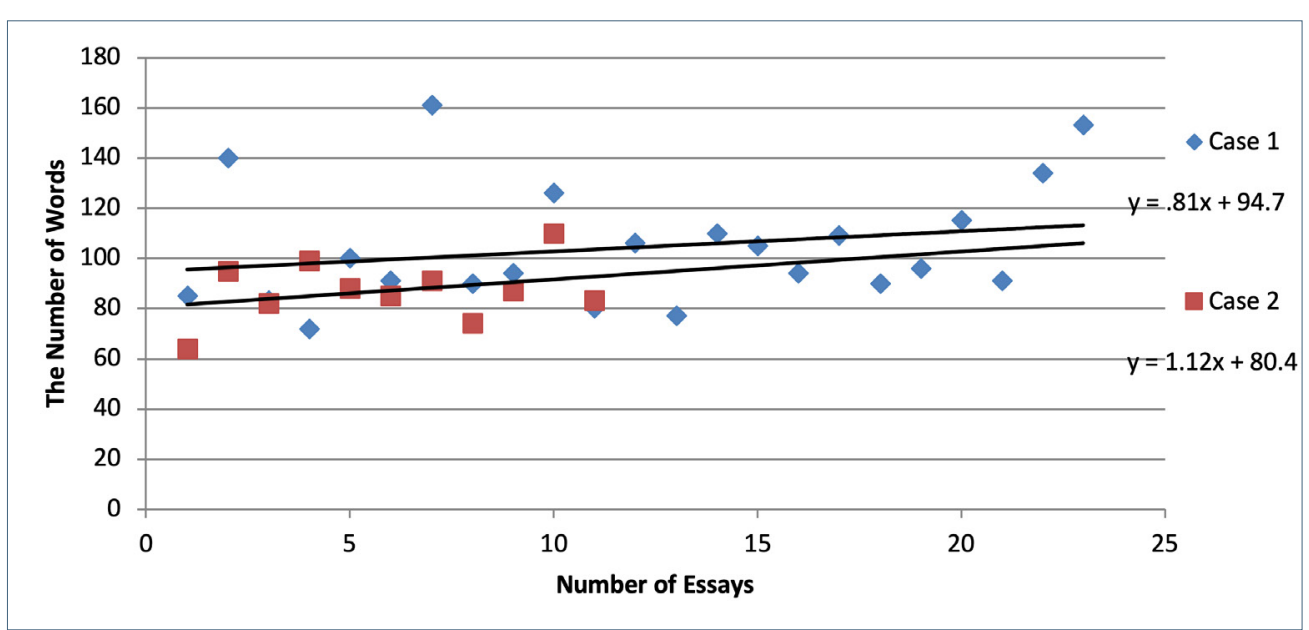

Figure 1. Total number of words used in each essay in Case 1 (Student A) and Case 2 (Student B).

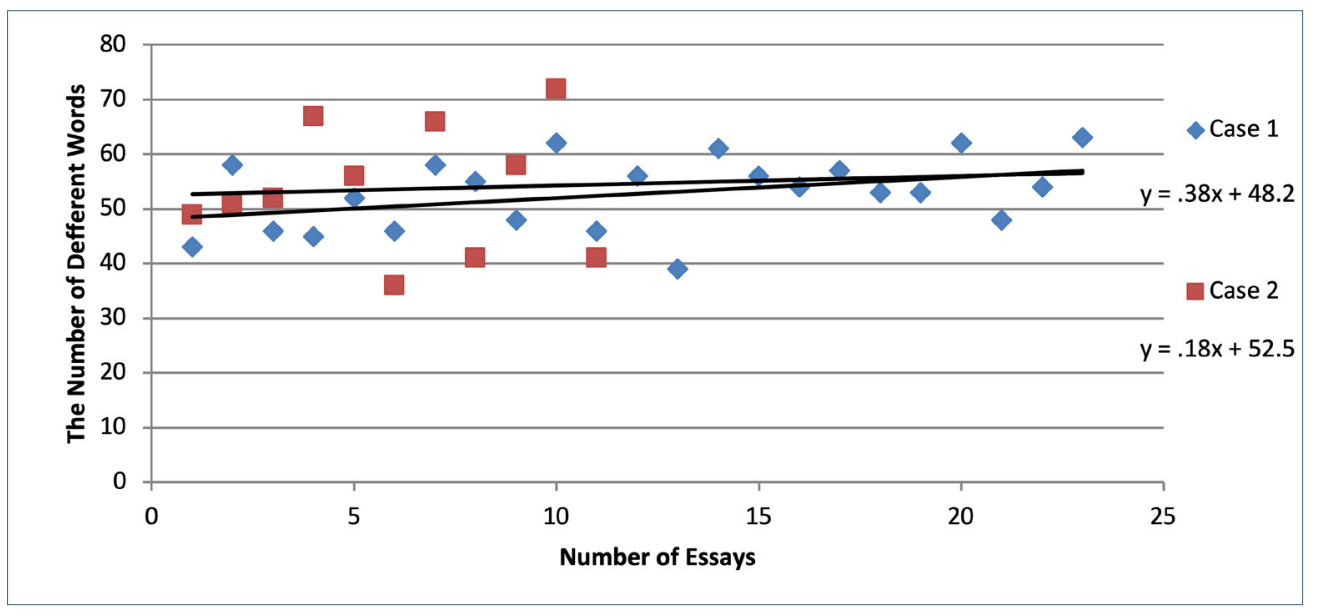

Figure 2. Total number of different words used in each essay in Case 1 (Student A) and Case 2 (Student B).

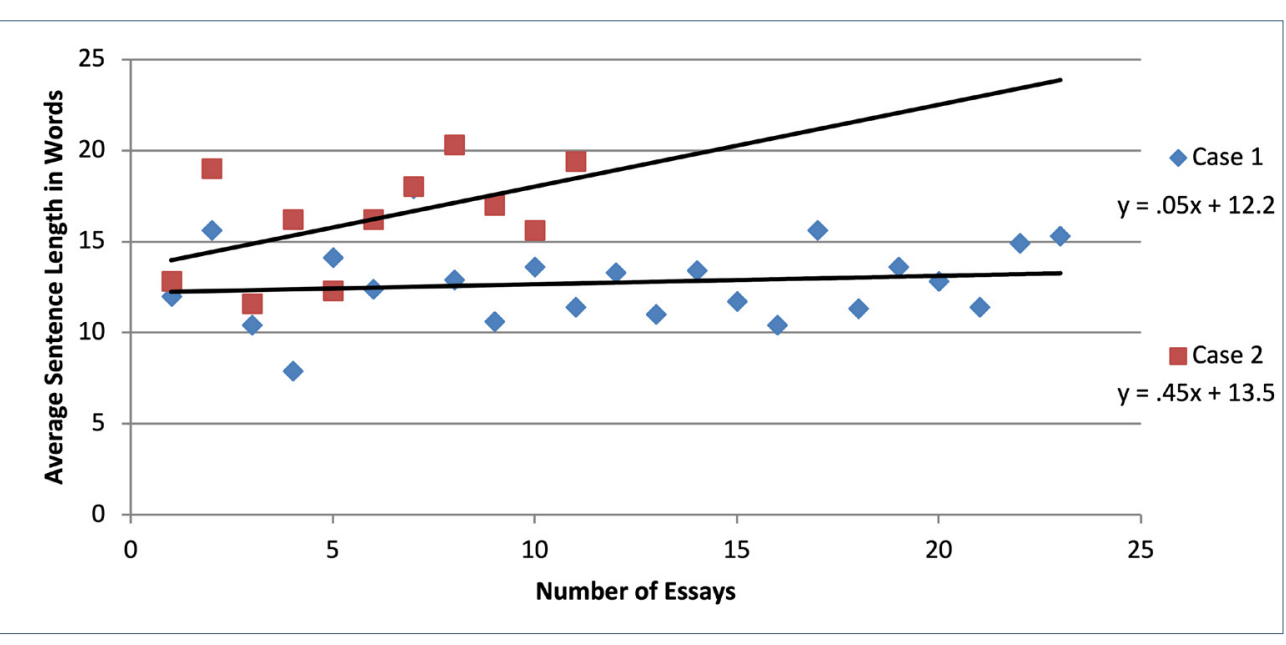

Figure 3. Average sentence length in words for each essay in Case 1 (Student A) and Case 2 (Student B).

The four additional cases showed similar tendencies, though one student did not turn in all his essays and thus his results are based on eight submitted essays. These students were given general comments on essay structure but little or no grammar correction feedback. As with the Students A and B, fluency measures were calculated and, with one exception, all showed least squares regression lines with positive slopes. The exception was the student labeled Case 6, for whom the number of words per sentence decreased slightly (see Figures 4-6). 


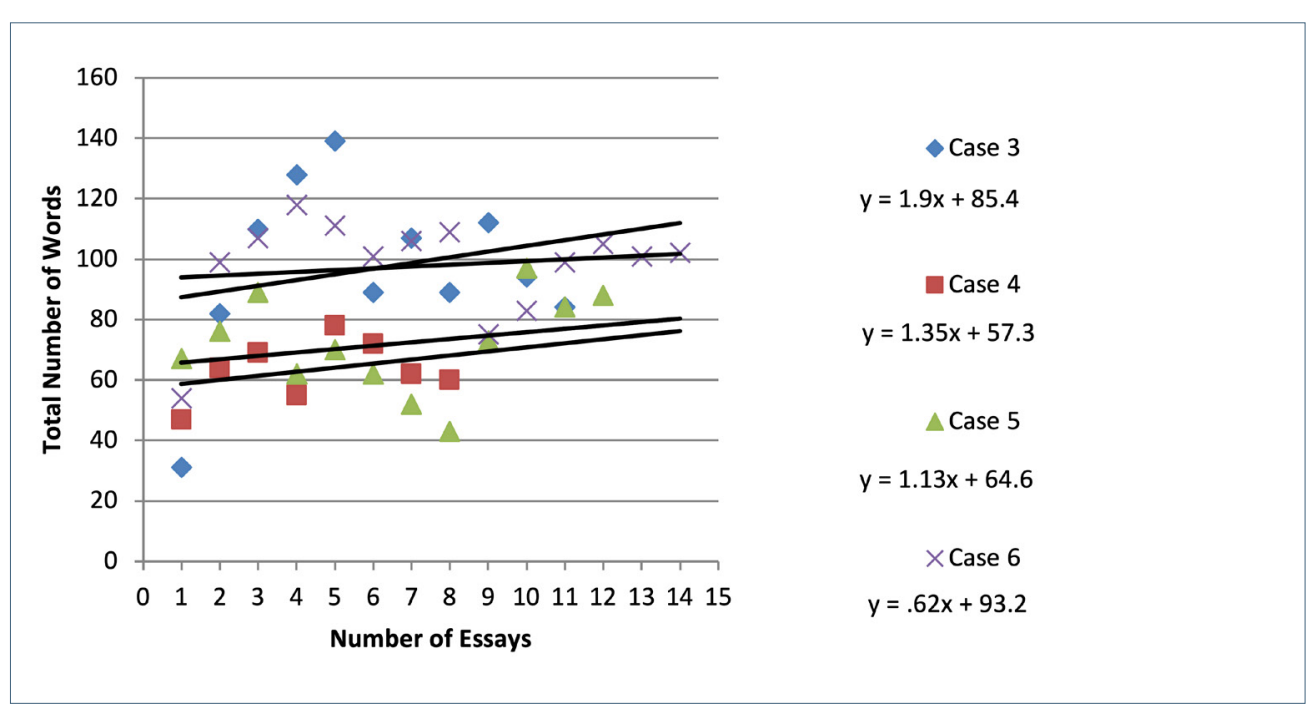

Figure 4. Total number of words used in each essay in Cases 3-6.

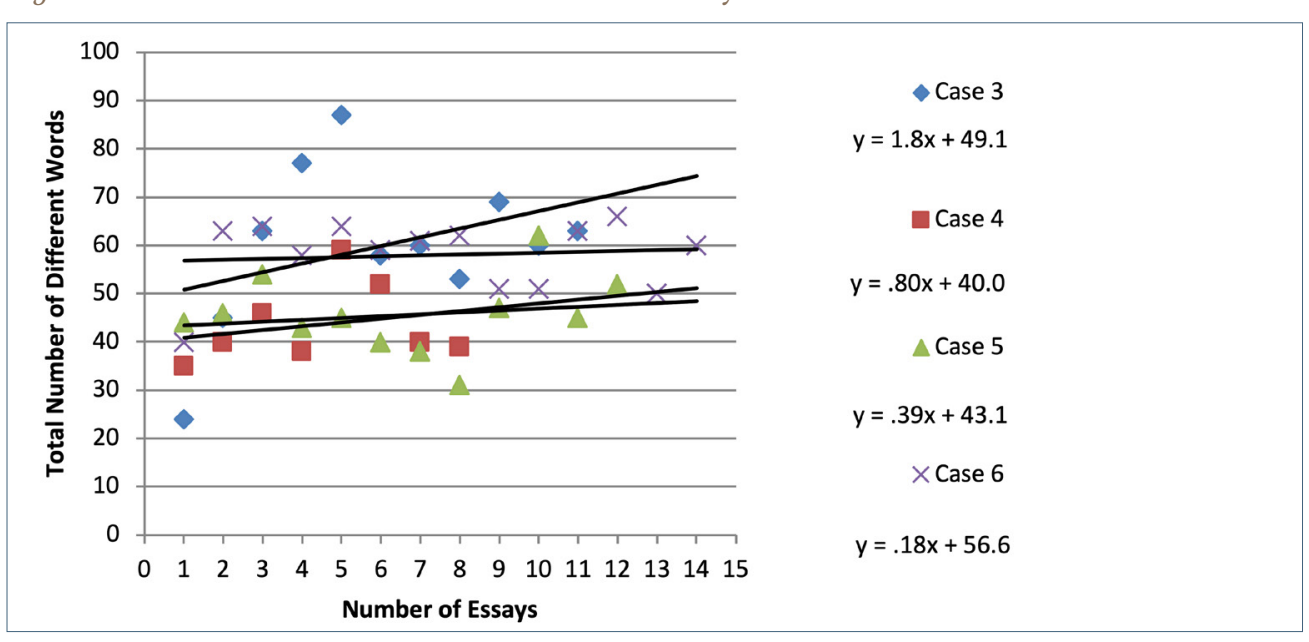

Figure 5. Total number of different words used in each essay in Cases 3-6.

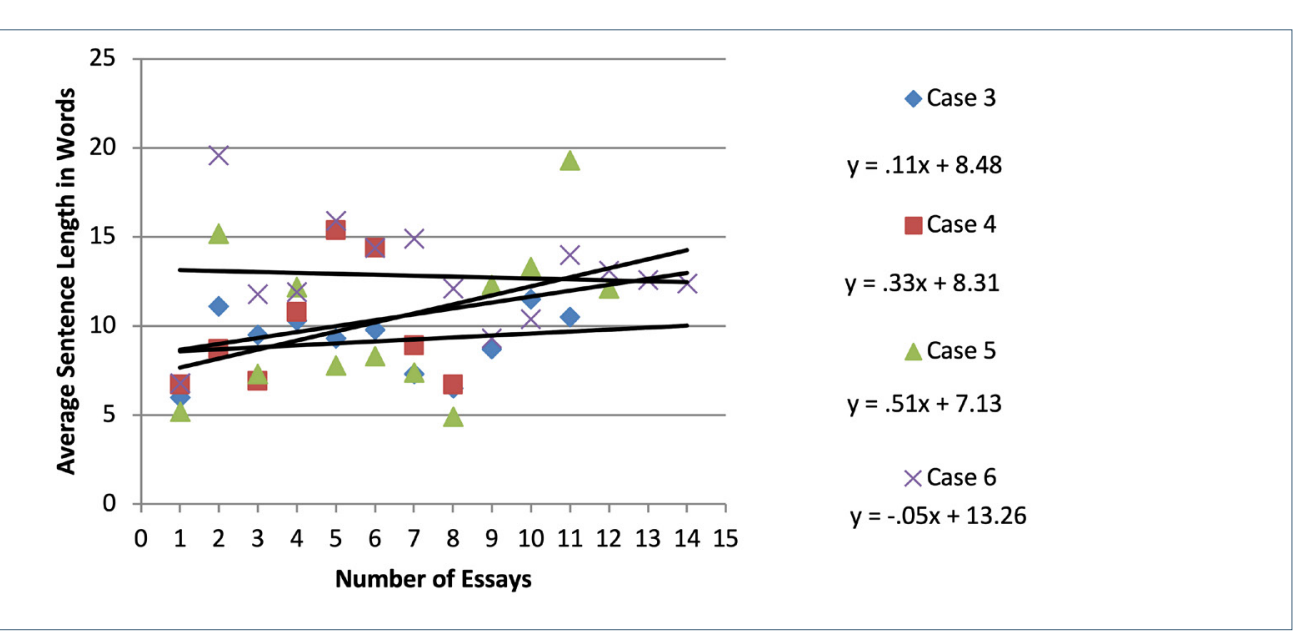

Figure 6. Average sentence length in words for each essay in Cases 3-6.

All four cases (3-6) were combined into one data set and analyzed using Spearman rank correlation. The results were $r=.26(p=.079)$ for total number of words, $r=.28(p=$ $.063)$ for total number of different words, and $r=.30(p=.049)$ for the average number of words per sentence.

Unlike the 10-minute writing cases described in Komiyama $(2016,2017)$, none of the students whose work is examined here were told to write as much as they could in the time allowed. Nonetheless, with one exception, all showed improved fluency on all the measures used.

In terms of grammatical accuracy, neither Student A nor Student B was free from mistakes even though they received corrective feedback and they were highly motivated to write accurate essays for the entrance examination (see Appendices A and B).

An increase in the use of postnominal modification structures would demonstrate the development of greater complexity, as suggested by Herder and King (2012). Of the fluency measures used in this study, an increase in the number of words per sentence essentially requires greater use of modifying expressions, both adnominal and adverbial. As one type of adnominal modifier, an increase in the use of postnominal modifiers is also tied to improved fluency. The numbers of postnominal modification structures used in all six cases were counted by type, but only total numbers are reported as the number of occurrences for some types was quite small. For Cases 3-6, the numbers of 
postnominal modifiers by number of essays written are shown both for each case as well as the average for all four cases (please refer to the boldface line and regression equation in Figure 8).

The total number of postnominal modifier constructions used in Cases 1 and 2 (Figure 7) and in Cases 3-6 (Figure 8) varied by topic but showed a clear increase over time; that is, the least squares regression lines show a positive slope.

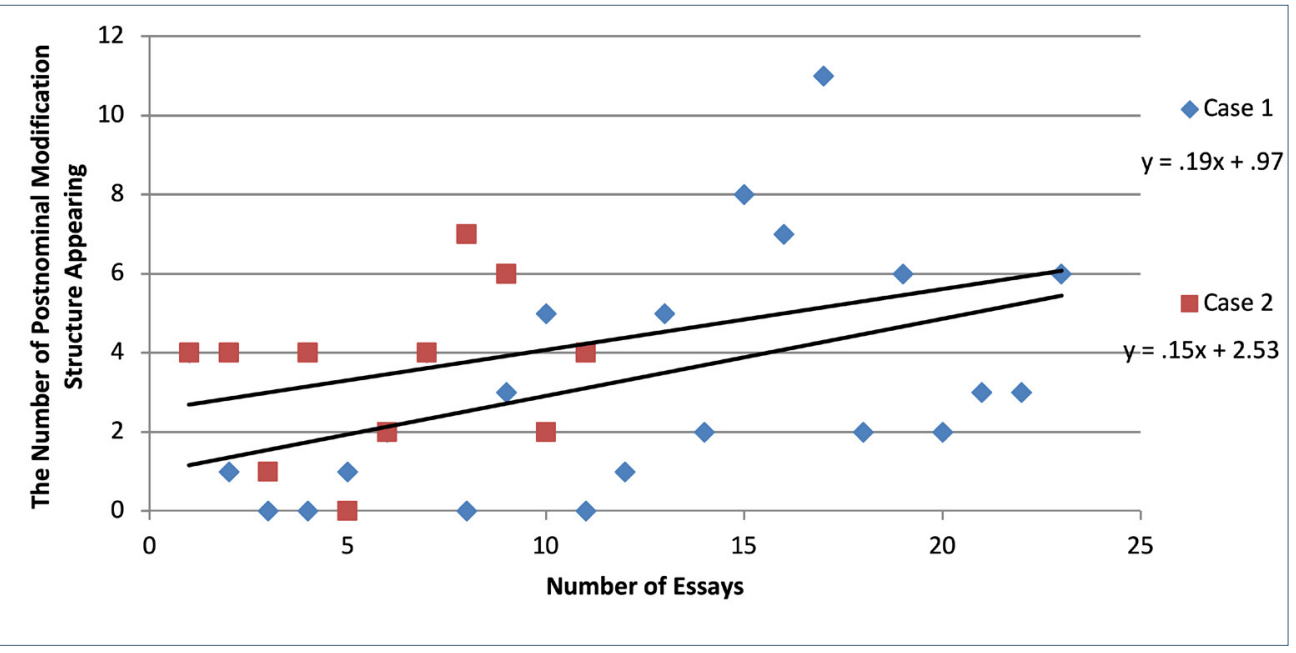

Figure 7. Postnominal modifiers used by Cases 1 and 2 in each essay.

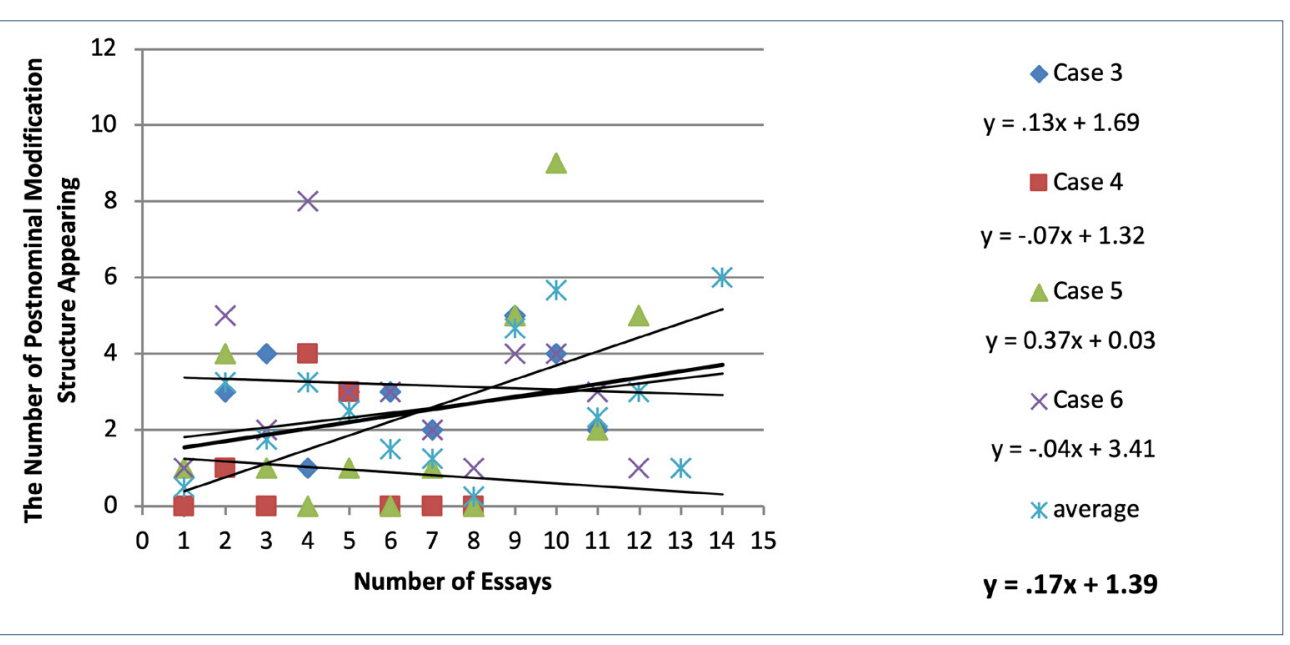

Figure 8. Postnominal modifiers used by Cases 3-6 in each essay.

\section{Discussion}

According to the slope of the linear regression lines, in every case the students had a tendency to write longer essays over time even when they were not required to do so. As the fluency measures of total number of words and number of words per sentence increased, later essays intuitively strike the reader as better than the earlier essays, even when they have the same overall structure.

One hypothesis that would relate this intuition to the length-based fluency measures is that the better, later essays include more detail. The addition of modifiers, both prenominal and postnominal, would be compatible with this hypothesis.

The increase in the number of postnominal modification structures found in the averages of Cases 3-6 and individually for Cases 1 and 2 support the hypothesis that the intuitive impression of the better quality of the later essays may be due to a greater use of modifiers, in particular, postnominal modifiers. The same observation also supports the use of words per sentence as a measure of fluency. A sentence can only become longer by using more modifiers and usually by using more complex structures.

There was considerable variation in the number of postnominal expressions used in Cases 3-6; Cases 4 and 6 actually declined slightly over time and Cases 3 and 5 increased rather sharply. Not all students wrote on the same topics and it is possible that the topics chosen by Cases 4 and 6 did not lend themselves to this kind of construction, 
although it should be noted that Case 6 did write essays with eight and six instances of postnominal constructions. However, the average number of postnominal constructions used by Cases 3 through 6 plotted against the number of essays written showed almost the same rate of increase as Cases 1-2. This could be due to the choice of essay topics by Cases 1-2; they used entrance exam prep questions, which often take the form: Do you agree or disagree with the statement that .... It would be natural for their answer essays to include a sentence like, "I agree with the statement that ... because ..." This is a postnominal modification construction (appositive clause, Number 6 in the list given earlier). The other four cases wrote on topics assigned as homework, which did not take the same form.

Another reason that Cases 1-2 more consistently increased their use of these constructions could have been the effect of explicit feedback on grammar, vocabulary, paragraph structure, and general organization in encouraging them to use such grammatically more complex structures.

Previous studies (Komiyama 2016, 2017) showed that students improved in writing fluency and maintained or increased their knowledge of grammar as measured by standard tests with a 10-minute weekly writing exercise with feedback in the form of comments on the content of their writing and without explicit grammar correction. In the case studies reported here, two of the six participants received explicit grammar correction; the other four did not. Nevertheless, the pattern of improvement in the students' writing was the same on fluency measures and showed the same tendency in the use of postnominal modifiers. Even without having been instructed to write as much as they could in a fixed time period, all six students wrote longer essays, used more different words, and used longer sentences.

Of the many ways in which sentences could become longer and more flowing, the main way is an increase in modification structures. Prenominal and preverbal modification constructions are common in both Japanese and English, but postnominal modification is only used in English. An increase in postnominal modification could reflect an increase in fluency in English. In all six cases, an increase was found over the period of observation in the use of postnominal modifiers.

\section{Conclusions}

Writing is a skill neglected in high-school English education, primarily because of the perception that it requires a large amount of time and effort for effective feedback to students. The cases reported here, together with previous reports, show that writing exercises with content-based, as opposed to grammar correction, feedback is an effective method of improving students' writing skills. Previous studies reported a program using 10 minutes a week of classroom time; the case studies reported here used no classroom time but showed similar results.

Students' writing improved in fluency measures even over a short period with or without detailed grammar correction feedback. They wrote longer essays with a variety of different words and using longer sentences. One factor in their writing longer sentences was their increased use of postnominal modification constructions. The improvement was apparent even over a short period of time.

Part of the resistance on the part of Japanese high school English teachers to free- or semifree-writing activities lies in the belief that unfocused, explicit error correction is necessary for the writing exercise to be effective. With a typical class size of 40 or more students, provision of such feedback is highly time-consuming.

On one hand, when using postnominal modifiers, students who received error correction and instruction on overall organization of the essay showed greater improvement than those who did not receive such feedback. On the other hand, all students showed similar improvement on quantity-based fluency measures and all showed some increase in the use of postnominal modifiers. Having students write essays as homework or as a timed in-class activity is an effective method to develop writing skills within the constraints imposed by large class sizes and limited time. Writing is a productive skill, like speaking, but does not require the physical presence of an interlocutor. As such and contrary to the general reluctance of Japanese high school English teachers, it is an easily implemented, communicative language activity in the form of repeated short writing exercises with content-based feedback.

\section{Bio Data}

Kazue Komiyama has taught in Japanese high schools for 26 years and finished her doctoral course in language and culture at Kyoto University of Foreign Studies in March 2019. She obtained an MA in educational counseling at Eastern Michigan University and an MSEd in TESOL at Temple University Japan. Her interests include extensive writing, communicative teaching, and teacher training for early education. $<13 \mathrm{dc} 0001 @ g m a i l$. com>

\section{References}

Ehara, Y., Murakoshi, R., \& Parise, P. (2018, November). Using CEFR-j for assessing teacher workshops. Paper presented at JALT2018, Shizuoka, Japan. 
Fazio, F. L. (2001). The effect of corrections and commentaries on the journal writing accuracy of minority- and majority-language students. Journal of Second Language Writing, 10, 235-249. https://doi.org/10.1016/s1060-3743(01)00042-x

Ferris, D. (1999). The case for grammar correction in $\mathrm{L} 2$ writing classes: A response to Truscott (1996). Journal of Second Language Writing, 8, 1-11. https://doi.org/10.1016/s1060-3743(99)801106

Gallagher, N. (2001). Delta's key to the TOEFL test. McHenry, IL: Delta.

Herder S., \& King, R. (2012). Extensive writing: Another fluency approach for EFL learners. Extensive Reading World Congress Proceedings, 1, 128-130.

Kepner, C. G. (1991). An experiment in the relationship of types of written feedback to the development of second-language writing skills. The Modern Language Journal, 75(3), 305 313. https://doi.org/10.1111/j.1540-4781.1991.tb05359.x

Komiyama, K. (2016, August). 日本人高校生へのライティング指導が抱える問題---フィードバックをどう行 うか [Writing in a Japanese high school English class: The role of feedback]. Paper presented at LET Conference, Tokyo.

Komiyama, K. (2017). Ten-minute writing practice for Japanese high school students. In P. Clements, A. Krause, \& H. Brown (Eds.), Transformation in language education (pp. 362-368). Tokyo: JALT. Retrieved from https://jalt-publications.org/sites/default/files/pdf-article/jalt2016pcp-047.pdf

Komiyama, K. (2018).「英語表現」で伸ばす表現力 [Improving English expression ability in the "English Expression" class]. In The Japan Society of English Language Education. Kyoto, Japan: JASELE.

MEXT. (2012). 平成24年度「外部検定試験の活用による英語力の検証」報告書 [2012 Report on “English proficiency testing using external proficiency tests”]. Retrieved from http://www.mext.go.jp/a menu/kokusai/gaikokugo/1332393.htm

MEXT. (2018). 平成29年度「英語教育実施状況調査 (高等学校)」の結果 [Results of 2017 “Survey of the state of implementation of English language education (high schools)"]. Retrieved from http://www. mext.go.jp/component/a_menu/education/detail/__icsFiles/afieldfile/2018/04/06/1403469_02. pdf

Semke, H. D. (1984). Effects of the red pen. Foreign Language Annals, 17(3). 195-202. https://doi. org/10.1111/j.1944-9720.1984.tb01727.x

Someya, Y. (2009). オンライン版「英文語彙難易度解析プログラム」(Word Level Checker) の概要とその 応用可能性について [Guide to and application of the online English vocabulary difficulty analysi program (Word Level Checker)]. Retrieved from http://someya-net.com/wlc/readability.pdf

Truscott, J. (1996). The case against grammar correction in L2 writing classes. Language Learning, 46, 327-369. https://doi.org/10.1111/j.1467-1770.1996.tb01238.x

\section{Appendix A}

\section{Early Essay of Student A}

I agree with the idea that parents are the best teachers.

Firstly, parents always are in your house. If you need to help, you could be helped by your parents.

Secondly, I think our parents are the good sample of us. If you imitated the things that your parents do, you could be good person like your parents.

Thirdly, your parents can teach is the things that high school teachers can't teach us.

I think parents are the best teachers, because of these reasons.

\section{Late Essay of Student A}

I agree with the statement that study history and literature is more important for students than to study science and mathematics. It is because you can understand your country. When you study history and literature, you can learn tradition in your country. Even if you study science and mathematics, you can not learn tradition in your country. It is good for you to learn old traditions because you may be able to find new things about your country.

Another reason is that you come to think more over by yourself. When you study history and literature, you will think over it. It is because the answer of history or literature is not necessary one answer.

On the other hand, whoever solves the question of science or mathematics, the answer will be the same. So, I think to study history and literature is more important for students than to study science and mathematics.

\section{Late Essay of Student A With Correction}

I agree with the statement that to study history and literature is more important for students than to study science and mathematics. It is because you can understand your country. When you study history and literature, you a can learn [the] tradition[s] in [of] your country. Even if you study science and mathematics, you can not learn (2)tradition in (1)your country\{'s\}. It is good for you to learn old tradition $\{\mathrm{s}\}$ because you may be able to find new things about your country.

Another reason is that you come to think more over by yourself. When you study history and literature, you will think over [about] it. It is because the answer of history or literature is not necessary\{ily\} one answer. 
On the other hand, whoever solves the question of science or mathematics, the answer will be the same. So, I think to study history and literature is more important for students than to study science and mathematics.

\section{Appendix B \\ First Essay of Student B With Correction}

(corrections in blue are only suggestions)

There are few shops that sell some food $\{s\}$ in my city, because the number of people living there has decreased every year. However, that is not true, actually, shops are [have gone] bankrupted, so people leave there. My city, Azuchi, was a famous place for selling and buying, because Oda Nobunaga built the biggest castle called Azuchi jyo [Jo]there. Furthermore, various people came from other places in Japan. For example

\section{Last Essay of Student 2 With Correction}

I would take a knife to a desert island because knives are so useful and not fragile. When it comes to living in [on] the desert island by yourself, you take it for granted that you need foods. Perhaps, there are some animals. But, if you don't have any tools to capture or kill them, you may not avoid dying. However, with a knife, you can get foods, and strip [take] their skins to make clothes and boots and so on. Furthermore, when you cook, eat, or fish, you must [would] want something [a fire] to set [cook] them on fire. At that time, you are [would be] able to produce fire with a knife and pebbles. 